\title{
Locomotor and Reinforcing Effects of Pentedrone, Pentylone and Methylone in Rats
}

Mehrak Javadi-Paydar ${ }^{1}$, Jacques D. Nguyen ${ }^{1}$, Sophia A. Vandewater ${ }^{1}$, Tobin J. Dickerson ${ }^{2}$ and Michael A. Taffe ${ }^{1}$

${ }^{1}$ Department of Neuroscience; ' 2 Department of Chemistry; The Scripps Research Institute; La Jolla, CA, USA

Address Correspondence to: Dr. Michael A. Taffe, Department of Neuroscience, SP30-2400; 10550 North Torrey Pines Road; The Scripps Research Institute, La Jolla, CA 92037; USA; Phone:

+1.858.784.7228; Fax: +1.858.784.7405; Email: mtaffe@scripps.edu 


\section{Abstract}

The broad diversity of synthetic cathinone psychostimulant drugs that are available to users complicates research efforts to provide understanding of health risks. Second generation cathinones pentedrone and pentylone are distinguished from each other by the 3,4-methylenedioxy structural motif (which distinguishes methamphetamine from 3,4-methylenedioxymethamphetamine) and each incorporates the $\alpha$-alkyl chain motif contained in the transporter-inhibitor cathinones $(3,4-$ methylenedioxypyrovalerone (MDPV), $\alpha$-pyrrolidinopentiophenone ( $\alpha-P V P))$ but not in the monoamine releasers (mephedrone, methylone). Studies were conducted in male and female Wistar rats to compare locomotor and thermoregulatory effects of pentedrone, pentylone and methylone using an implanted radiotelemetry system. Reinforcing effects were assessed in female Wistar rats trained in the intravenous self-administration (IVSA) procedure and subjected to dose-substitution $(0.025-0.3 \mathrm{~m} / \mathrm{gkg} / \mathrm{inf})$ under a fixed-ratio 1 response contingency. Pentedrone, pentylone and methylone dose-effect curves were contrasted with those for $\alpha-P V P$ and $\alpha$-pyrrolidinohexiophenone ( $\alpha-P H P)$. Dose dependent increases in locomotion were observed after intraperitoneal injection of pentylone $(0.5-10.0 \mathrm{mg} / \mathrm{kg})$, pentedrone $(0.5-$ $10.0 \mathrm{mg} / \mathrm{kg}$ ) or mephedrone $(0.5-10.0 \mathrm{mg} / \mathrm{kg})$ in male and female rats. The maximum locomotor effect was similar across drugs but lasted longest after pentedrone. Mean body temperature did not vary systematically more than $0.5^{\circ} \mathrm{C}$ after pentedrone or pentylone in either sex. A sustained hyperthermia $\left(0.4-0.8^{\circ} \mathrm{C}\right)$ was observed for four hours after $10 \mathrm{mg} / \mathrm{kg}$ methylone in male rats. More infusions of pentedrone or pentylone were self-administered compared with methylone, but all three were less potent than $\alpha-P V P$ or $\alpha-P H P$. These studies support the inference that second generation cathinones pentylone and pentedrone have abuse liability greater than that of methylone. 


\section{Introduction}

Recreational use of cathinone derivative psychostimulant drugs has increased over the past decade (Madras, 2017), yet the broad diversity of the drugs that are available to users (Brunt et al, 2017; Odoardi et al, 2016) has complicated research efforts to provide understanding of various health risks (Aarde and Taffe, 2017; Angoa-Perez et al, 2017; Negus and Banks, 2017; Papaseit et al, 2017). The US DEA placed both pentedrone and pentylone under temporary Schedule I control in March of 2014 and this action was finalized in 2017 (Drug Enforcement Administration, 2014, 2017).

These compounds have been detected in forensic casework (Adamowicz et al, 2016; Elliott and Evans, 2014), and there is evidence for health threatening toxic effects of pentylone (Liakoni et al, 2015) as well as for pentedrone in combination with other cathinone derivatives (Liveri et al, 2016; Sykutera et al, 2015). Second-<smiles>CCCC(NC)C(=O)c1ccccc1</smiles>

\section{Pentedrone} generation compounds such as pentylone and pentedrone have received less research attention compared with mephedrone, methylone, 3,4methylenedioxypyrovalerone (MDPV) and a-pyrrolidinopentiophenone ( $\alpha$-PVP).

Although prior preclinical evidence is not comprehensive, there is<smiles>CCCC(NC)C(=O)c1ccc2c(c1)OCO2</smiles>

Pentylone evidence that pentedrone increases locomotor activity in mice (Gatch et al, 2015; Hwang et al, 2017), supports intravenous self-administration (IVSA) in male Wistar rats (Hwang et al, 2017) and substitutes for the discriminative stimulus effect of methamphetamine and cocaine in male rats (Gatch et al, 2015). Pentylone likewise increases locomotor activity in mice and substitutes for methamphetamine and cocaine (Gatch et al, 2015). In contrast the effects of methylone are better established. Methylone supports IVSA in both male and<smiles>CNC(C)C(=O)c1ccc2c(c1)OCO2</smiles>
Methylone

Figure 1: Chemical structures of the substituted cathinones under investigation. female rats (Aarde et al, 2015b; Creehan et al, 2015; Nguyen et al, 2016b; Schindler et al, 2015; Vandewater et al, 2015; Watterson et al, 2012), facilitates intracranial self-stimulation reward in rats (Bonano et al, 2014), can condition a place preference in mice (Karlsson et al, 2014), substitutes for the discriminative stimulus effects of cocaine or methamphetamine in rats (Gatch et al, 2013) and increases body temperature and locomotor activity in rats and mice (Gatch et al, 2013; Grecco and Sprague, 2016; 
Kiyatkin et al, 2015; Marusich et al, 2012). Despite the fact that methylone is structurally similar to 3,4methylenedioxymethamphetamine (MDMA) the pre-clinical self-administration data suggests that methylone exhibits enhanced liability for compulsive use compared with that of MDMA (Nguyen et al, 2016b; Vandewater et al, 2015; Watterson et al, 2012).

The diversity of cathinone derivatives permits further investigation of the role of various substitution moieties common to both amphetamine and cathinone drugs of abuse. In this study, we investigate the 3,4-methylenedioxy motif (see Figure 1) in the contrast of the effects of pentedrone with pentylone. This motif, when added to methamphetamine to produce MDMA, confers reduced rewarding potency and efficacy (Dalley et al, 2007; Schenk, 2009; Vandewater et al, 2015), reduced locomotor potency (Huang et al, 2012; Miller et al, 2013a), reduced efficacy to induce stereotyped, repetitive behavior and increased thermoregulatory disruption (Miller et al, 2013a). In contrast, the presence of the 3,4-methylenedioxy substitution produces no change in vivo in the context of the closely related, restricted transporter inhibitor cathinones $\alpha-P V P$ and MDPV which exhibit similar efficacy and potency on both locomotor and self-administration assays in rats (Aarde et al, 2015a). Pentedrone and pentylone also include the extended alkyl-tail carbon chain that is present on MDPV and a-PVP which may be related to the restriction of those drugs to transporter inhibition. This might predict that the 3,4methylenedioxy motif has minimal impact on these additional compounds which lack the pyrrolidine ring of MDPV and $\alpha-P V P$.

Pentedrone and pentylone exhibit negligible dopamine or norepinephrine release (Eshleman et al, 2017; Simmler et al, 2014), however some serotonin release was observed for pentylone in one of the reports and methylone is more effective than either compound (Simmler et al, 2014). The inhibition of the serotonin transporter (SERT) by pentylone is 16 -fold higher than inhibition by pentedrone, similar to the 17-fold higher affinity of MDMA over methamphetamine. In addition, pentylone inhibits dopamine transporter (DAT) activity with a potency of about half that of pentedrone whereas DAT inhibition caused by methamphetamine is 17 -fold higher than that of MDMA. The ratio of potencies for inhibiting the DAT versus the SERT is 54 for pentedrone, compared with 6.2 for pentylone, 3.2 for methylone, 22 for methamphetamine and 0.08 for MDMA (Simmler et al, 2013; Simmler et al, 2014). The in vitro 
pharmacology therefore predicts that pentedrone would be significantly more potent as a locomotor stimulant or reinforcer compared with pentylone and methylone; however, the difference should be less pronounced than the potency difference between MDMA and methamphetamine. The potential of pentylone to release serotonin predicts reduced efficacy compared with pentedrone. The present study was conducted to evaluate these hypotheses in vivo using IVSA techniques (Aarde et al, 2013a; Aarde et al, 2015a; Creehan et al, 2015) and a rat locomotor assay that has been used to evaluate the locomotor stimulant effects of MDPV, a-PVP, methamphetamine and MDMA (Aarde et al, 2015a; Miller et al, 2013a). In these procedures, comparison of behavioral outcomes after a range of doses can be used to infer differences in potency (the dose at which a given effect occurs) and efficacy (the maximum effect observed for any dose). These differences, if established, can then be used to support predictions or inferences about the relative abuse liability when translated to the recreational use context.

\section{Methods}

\subsection{Subjects}

Male $(\mathrm{N}=8)$ and female $(\mathrm{N}=33)$ Wistar (Charles River, New York) rats entered the laboratory at 10 weeks of age and were housed in humidity and temperature-controlled $\left(23 \pm 1^{\circ} \mathrm{C}\right)$ vivaria on $12: 12$ hour light:dark cycles. Experimental procedures took place during the animals' dark cycle. Animals had ad libitum access to food and water in their home cages. All procedures were conducted under protocols approved by the Institutional Care and Use Committees of The Scripps Research Institute and in a manner consistent with the Guide for the Care and Use of Laboratory Animals (National Research Council (U.S.). Committee for the Update of the Guide for the Care and Use of Laboratory Animals. et al, 2011).

\subsection{Drugs}

Drugs were dissolved in physiological saline for the i.p. or i.v. routes of administration. Pentylone $\mathrm{HCl}$, pentedrone $\mathrm{HCl}$, $\alpha$-pyrrolidinopentiophenone $\mathrm{HCl}(\alpha-P V P)$ and $\alpha$-pyrrolidinohexiophenone $\mathrm{HCl}(\alpha-$ 
PHP) were obtained from Cayman Chemical. Methylone $\mathrm{HCl}$ was obtained from NIDA Drug Supply.

Dosing is expressed as the salt.

\subsection{Procedures}

\subsubsection{Surgery}

2.3.1.1 Radiotransmitter Implantation: Rats were anesthetized with an isoflurane/oxygen vapor mixture (isoflurane 5\% induction, 1-3\% maintenance), and sterile radiotelemetry transmitters (Data Sciences International; TA-F40) were implanted in the abdominal cavity through an incision along the abdominal midline posterior to the xyphoid space as previously reported (Aarde et al, 2015a; Miller et al, 2013a; Wright et al, 2012). Absorbable sutures were used to close the abdominal muscle incision and the skin incision was closed with the tissue adhesive (3M Vetbond Tissue Adhesive; 3M, St Paul, MN). A minimum of 7 days was allowed for surgical recovery prior to starting experiments. For the first three days of the recovery period, an antibiotic Cefazolin (Hikma Farmaceutica, Portugal; 0.4 mg/kg, i.m. in sterile water Day 1, s.c. Day 2-3) and an analgesic flunixin (FlunixiJect, Bimeda USA, Oakbrook Terrace, IL; $2.5 \mathrm{mg} / \mathrm{kg}$, s.c. in saline) were administered daily.

\subsubsection{Intravenous catheter implantation: Rats were anesthetized with an isoflurane/oxygen vapor} mixture (isoflurane $5 \%$ induction, 1-3 \% maintenance) and prepared with chronic intravenous catheters as described previously (Aarde et al, 2015a; Aarde et al, 2013b; Miller et al, 2013b; Nguyen et al, 2016b). Briefly, the catheters consisted of a 14-cm length polyurethane based tubing (MicroRenathane $\AA$, Braintree Scientific, Inc, Braintree MA, USA) fitted to a guide cannula (Plastics one, Roanoke, VA) curved at an angle and encased in dental cement anchored to an $\sim 3-\mathrm{cm}$ circle of durable mesh. Catheter tubing was passed subcutaneously from the animal's back to the right jugular vein. Catheter tubing was inserted into the vein and secured gently with suture thread. A liquid tissue adhesive was used to close the incisions (3M ${ }^{\mathrm{TM}}$ Vetbond ${ }^{\mathrm{TM}}$ Tissue Adhesive; 1469S B). A minimum of 4 days was allowed for surgical recovery prior to starting an experiment. For the first 3 days of the recovery period, an antibiotic (cephazolin) and an analgesic (flunixin) were administered daily. During testing and training, intra-venous 
catheters were flushed with $\sim 0.2-0.3 \mathrm{ml}$ heparinized $(32.3 \mathrm{USP} / \mathrm{ml}$ ) saline before sessions and $\sim 0.2-0.3$ $\mathrm{ml}$ heparinized saline containing cefazolin $(100 \mathrm{mg} / \mathrm{ml})$ after sessions. Starting in the second week of IVSA training, the catheter patency was assessed after the last session of the week via administration through the catheter of $\sim 0.2 \mathrm{ml}(10 \mathrm{mg} / \mathrm{ml}$ ) of the ultra-short-acting barbiturate anesthetic Brevital sodium (1 \% methohexital sodium; Eli Lilly, Indianapolis, IN). Animals with patent catheters exhibit prominent signs of anesthesia (pronounced loss of muscle tone) within $3 \mathrm{~s}$ after infusion. Animals that failed to display these signs were considered to have faulty catheters and were discontinued from the study. Data that were collected prior to failing this test and after the previous passing of this test were excluded from analysis.

\subsubsection{Radiotelemetry Measures of Locomotor Activity and Body Temperature}

Locomotor activity and temperature data were collected while animals were housed in clean standard plastic home-cages (thin layer of bedding) in a dark testing room (dim red-light illumination), separate from the vivarium, during the (vivarium) dark cycle. Radiotelemetry transmissions were collected via receiver plates (Data Sciences International; RPC-1) placed under the cages as described in prior investigations (Aarde et al, 2013b; Miller et al, 2013a; Taffe et al, 2015; Wright et al, 2012). The ambient temperature for the studies was $22 \pm 1{ }^{\circ} \mathrm{C}$. Sessions started with a 30 -minute interval in the recording cage to determine a pre-treatment baseline of activity and temperature. Thereafter animals were injected with the scheduled challenge drug/vehicle and then returned to their individual recording cages. The three telemetry samples taken prior to moving the rat to the inhalation chamber were used as the pre-treatment baseline for analysis. Primary analysis focused on the average activity rate (counts per minute) and body temperature $\left({ }^{\circ} \mathrm{C}\right)$ in 30 minute intervals as derived from the primary 5 min sampling bins. Data are timed to the injection and the "30 minute" time bin reflects the average of 6 samples collected from 5 to 30 minutes after return to the recording chamber following injection. Any missing body temperature data (e.g., due to radio interference or animal's location within the chamber at the time of sampling) was interpolated across preceding and succeeding recorded values. 


\subsection{Experiments}

2.4.1 Temperature and Activity in Male Rats: Male Wistar rats (Group 1; N=8; 33 weeks of age and a mean of $589 \mathrm{~g}$ at the start of this study) were initially exposed ( 15 weeks of age) to inhalation of propylene glycol (PG) vapor versus MDMA (400 mg/ml in PG) for 40 minutes in a method previously described (Nguyen et al, 2016a). No other experiments were performed with this group until the current experiment. Rats were tested first with pentedrone $(0.0,0.5,1.0,5.0 \mathrm{mg} / \mathrm{kg}$, i.p.), then $\alpha-P P P(0.0,0.5$, $1.0,5.0 \mathrm{mg} / \mathrm{kg}$, i.p.) and then pentylone $(0.0,0.5,1.0,5.0 \mathrm{mg} / \mathrm{kg}$, i.p.) with dose order randomized withindrug compound. Doses were initially selected based on prior and ongoing locomotor studies in the laboratory with compounds with a similar range of in vitro pharmacological effects. Following this, animals were tested with $10 \mathrm{mg} / \mathrm{kg}$, i.p. of pentedrone, $\alpha$-PPP, and pentylone in a randomized order to further determine the dose-effect range. Next, rats were tested with saline and $5.0 \mathrm{mg} / \mathrm{kg}$, i.p. of $\alpha-P V P$, methamphetamine or MDPV in a randomized order. One animal was euthanized after the methamphetamine condition by protocol due to unregulated elevated body temperature, thus $\mathrm{N}=7$ for the subsequent studies. The final experiment was to evaluate the effects of treatment with methylone $(0.0$, $0.5,1.0,5.0 \mathrm{mg} / \mathrm{kg}$, i.p.) in a randomized order followed by methylone (10 mg/kg, i.p.).

2.4.2 Temperature and Activity in Female Rats: Female Wistar rats (Group 2; N=8; 12 weeks of age and a mean of $222 \mathrm{~g}$ at the start of this study) were initially recorded in a habituation session with no treatments. For this study, rats were evaluated first with $\alpha$-PPP $(0.0,1.0,5.0,10.0 \mathrm{mg} / \mathrm{kg}$, i.p. $)$, then pentedrone $(0.0,1.0,5.0,10.0 \mathrm{mg} / \mathrm{kg}$, i.p. $)$ then pentylone $(0.0,1.0,5.0,10.0 \mathrm{mg} / \mathrm{kg}$, i.p. $)$ and finally methylone $(0.0,1.0,5.0,10.0 \mathrm{mg} / \mathrm{kg}$, i.p. $)$.

2.4.3 Intravenous Self-Administration in Female Rats: Female Wistar rats (Group 3; N=17; 10 weeks of age at the start of this study) were prepared with intravenous catheters and trained to self-administer $\alpha$ PVP (N=8; $0.05 \mathrm{mg} / \mathrm{kg}$ per infusion) or pentedrone (N=9; $0.2 \mathrm{mg} / \mathrm{kg} / \mathrm{inf})$ using a fixed-ratio 1 (FR1) response contingency. Doses were selected from prior self-administration studies and ongoing locomotor studies to result in similar numbers of infusions throughout the acquisition interval. Following 13 sessions 
of acquisition the training doses were halved for another seven sessions (data not shown). Thereafter, animals were subjected to dose substitution of different cathinones $(0.0,0.025,0.05,0.1,0.3 \mathrm{mg} / \mathrm{kg} / \mathrm{inf})$ in a randomized order, with the restricted transporter-inhibitor compounds serving as positive controls / validation studies. The animals first completed a dose-substitution series with their respective training drug. The pentedrone trained animals next completed the series in the following order: $\alpha-P P P, \alpha-P V P$, pentylone, $\alpha$-PHP, methylone. The $\alpha$-PVP group next completed additional series as follows: $\alpha-P P P$, pentedrone, pentylone, a-PHP, methylone. A follow-up study including saline and doses $(0.0125,0.025$, $0.1 \mathrm{mg} / \mathrm{kg} / \mathrm{inf}$ ) of $\alpha-P V P$ and $\alpha-P H P$ was conducted to further determine the dose-effect range for these two compounds.

\subsection{Data Analysis}

Measures of locomotor activity (rate of activity counts per minute) were analyzed by repeated-measures Analysis of Variance (rmANOVA) with Time Post-injection and Drug Dose (or Drug for the $10 \mathrm{mg} / \mathrm{kg}$ comparison) as within-subjects factors. Body temperature data were not formally analyzed as mean changes of $>5^{\circ} \mathrm{C}$ were only observed sporadically. The number of infusions obtained in the IVSA experiments was analyzed by rmANOVA with Sessions (acquisition only), Drug identity and/or Dose (dose-substitution only) as within-subjects factors. Significant main effects from the rmANOVA were further analyzed with post hoc multiple comparisons analysis using the Tukey procedure. The criterion for significant results was at $P<0.05$ and all analyses were conducted using Prism 6 or 7 for Windows (v. 6.02, v. 7.00; GraphPad Software, Inc, San Diego CA).

\section{Results}

\subsection{Effect of Substituted Cathinones on Activity and Body Temperature in Male Rats}

\subsubsection{Activity:}


Intraperitoneal injection of pentylone, pentedrone and methylone all significantly increased locomotor activity in a dose-dependent manner in the male rats (Figure 2).

3.1.1.1 Pentylone: The analysis confirmed a significant effect of Time $[F(8,56)=11.71 ; P<0.0001]$, of Dose $[F$ $(3,21)=12.63 ; P<0.0001]$ and of the interaction of factors $[F(24,168)=2.39 ; P=0.0007]$. The post-hoc test further confirmed that activity was significantly higher after injection of $5.0 \mathrm{mg} / \mathrm{kg}$ pentylone compared with the vehicle (30-150 minutes post-injection), with the 0.5 $\mathrm{mg} / \mathrm{kg}$ dose (30-90, 150 minutes post-injection) and with the $1.0 \mathrm{mg} / \mathrm{kg}$ dose $(60-120,210$ minutes post-injection).

3.1.1.2 Pentedrone: The analysis confirmed a significant effect of Time $[F(8,56)=3.43 ; P<0.005]$. The post-hoc test confirmed activity was significantly higher relative to baseline $30-90$ minutes after injection of $5.0 \mathrm{mg} / \mathrm{kg}$ pentedrone but not for any other of the conditions.

3.1.1.3 Methylone: The analysis confirmed a significant effect of Time $[F(8,48)=26.26 ; P<0.0001]$ and of the interaction of Time with Dose $[F(24,144)=2.66$; $\mathrm{P}<0.0005]$. The post-hoc test further confirmed that activity was significantly higher 30-90 minutes after injection of $5.0 \mathrm{mg} / \mathrm{kg}$ Methylone compared with all other conditions.
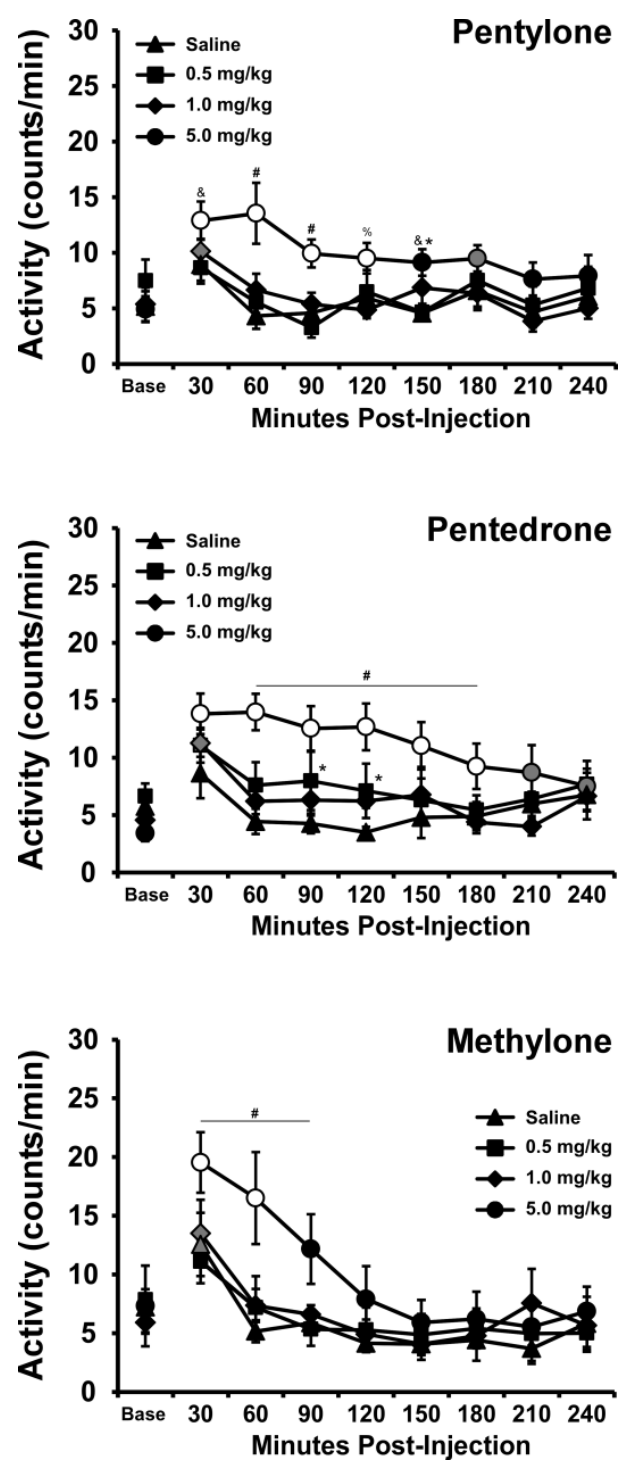

Figure 2: Mean ( \pm SEM) activity rates of male rats following i.p. injection with pentylone $(N=8)$, pentedrone $(N=8)$ and methylone $(N=7)$. Significant differences from the baseline, within drug/dose, are indicated by symbols filled with gray and from both vehicle and baseline with open symbols. Significant differences from $0.5 \mathrm{mg} / \mathrm{kg}$ and $1.0 \mathrm{mg} / \mathrm{kg}$ doses are indicated by \#, from $0.5 \mathrm{mg} / \mathrm{kg}$ by \&, from $1.0 \mathrm{mg} / \mathrm{kg}$ by $\%$ and from vehicle (only) by ${ }^{*}$. Base = baseline. 
3.1.1.4 Pentylone/Pentedrone/Methylone (10 $\mathrm{mg} / \mathrm{kg})$ : The analysis confirmed significant effects of Time $[F(8,216)=32.0 ; P<0.00011]$, of Drug $[F(3,27)=5.99 ; P<0.005]$ and of the interaction of Time with Drug $[F(24,216)=6.63 ; P<0.0001]$, see Figure 3. The post-hoc test furthermore confirmed that

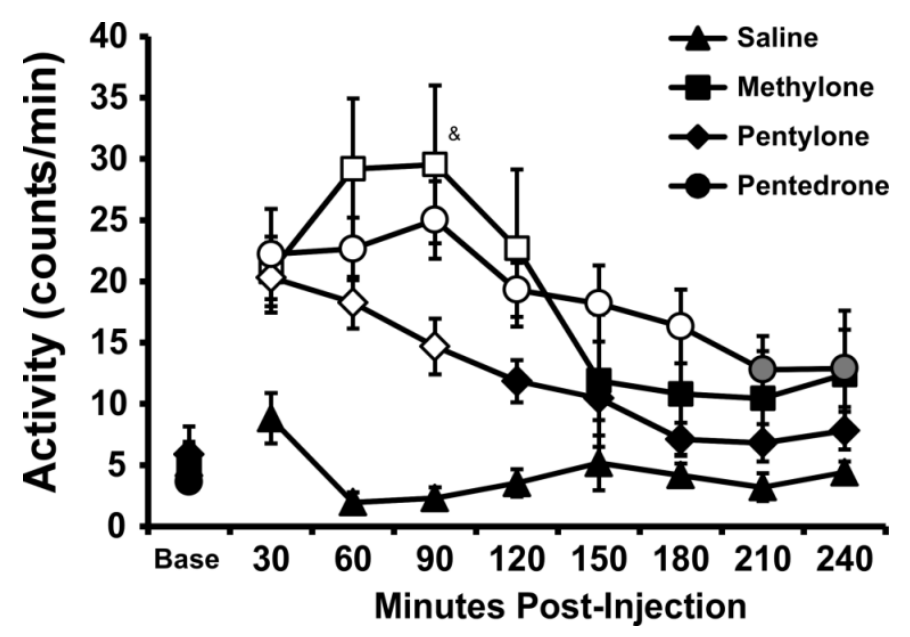

Figure 3: Mean ( \pm SEM) activity rates of male rats following injection with the vehicle or $10 \mathrm{mg} / \mathrm{kg}$, i.p. pentylone $(\mathrm{N}=8)$, pentedrone $(N=8)$ and methylone $(N=7)$. Sig differences from the baseline, within drug/dose, are indicated by symbols filled with gray and from both vehicle and baseline with open symbols. A significant difference from pentylone is indicated by \&. Base = baseline.

activity was significantly elevated over the vehicle condition after $10 \mathrm{mg} / \mathrm{kg}$ pentylone [30-90 minutes post-injection], after $10 \mathrm{mg} / \mathrm{kg}$ pentedrone [30-180 minutes post- injection] and after $10 \mathrm{mg} / \mathrm{kg}$ methylone (30-120 minutes post-injection). Furthermore, activity was significantly higher after methylone compared with pentylone 90 minutes post-injection.

\subsubsection{Temperature:}

Body temperature was not substantially changed in most of these studies; in the vast majority of cases mean body temperature did not vary more than $0.5^{\circ} \mathrm{C}$ from the baseline temperature (data not shown). Episodic temperature change in excess of a $0.5^{\circ} \mathrm{C}$ deviation included mean temperature changes of $+0.58^{\circ} \mathrm{C}$ at $60 \mathrm{~min}$ after $5.0 \mathrm{mg} / \mathrm{kg}$ pentedrone, $+0.51^{\circ} \mathrm{C} 60$ minutes after $5.0 \mathrm{mg} / \mathrm{kg}$ pentylone and $-0.52^{\circ} \mathrm{C} 90$ minutes after $0.5 \mathrm{mg} / \mathrm{kg}$ pentylone. Sustained change was only observed after the 10 $\mathrm{mg} / \mathrm{kg}$ methylone dose, following which mean elevations of $0.71-0.84^{\circ} \mathrm{C}$ were observed $60-120$ minutes after injection and of $0.53-0.57^{\circ} \mathrm{C}$ from $150-240$ minutes after injection. 


\subsection{Effect of Substituted Cathinones on Activity and Body Temperature in Female Rats}

Intraperitoneal injection of pentylone, pentedrone and methylone all significantly increased locomotor activity in a dose-dependent manner in the female rats (Figure 4).

\subsubsection{Activity:}

3.2.1.1 Pentylone: The analysis confirmed significant effects of time $[F(8,56)=16.69 ; P<0.0001]$, of dose $[F(3,21)=7.91$; $\mathrm{P}<0.005]$ and an interaction of time with dose $[\mathrm{F}(24,168)=$ $2.24 ; P<0.005]$ on activity after injection of pentylone (Figure

4). The post-hoc test further confirmed that activity was significantly higher compared with vehicle after $5.0 \mathrm{mg} / \mathrm{kg}$ dose (30-60 minutes after injection) or the $10.0 \mathrm{mg} / \mathrm{kg}$ dose (30-150 minutes), and higher than $1 \mathrm{mg} / \mathrm{kg}$ dose after the 5 $\mathrm{mg} / \mathrm{kg}$ (60 minutes) or $10(60-150) \mathrm{mg} / \mathrm{kg}$ doses.

3.2.1.2 Pentedrone: Activity rates after injection of pentedrone (Figure 4) were significantly affected by time [F $(8,56)=24.25 ; P<0.0001]$, by dose $[F(3,21)=12.08$; $P<0.0001]$ and the interaction of time with dose $[F(24,168)=$ 5.86; $\mathrm{P}<0.0001]$. The post-hoc test confirmed activity was significantly higher after 5.0 or $10.0 \mathrm{mg} / \mathrm{kg}$ relative to vehicle or $1.0 \mathrm{mg} / \mathrm{kg}$, i.p. from $30-150$ minutes after injection. The activity increase after the $10 \mathrm{mg} / \mathrm{kg}$ dose remained significantly different from the vehicle or $1.0 \mathrm{mg} / \mathrm{kg}$ conditions to 210 minutes post-injection and was higher compared with the $5.0 \mathrm{mg} / \mathrm{kg}$ dose from $120-150$ minutes post-injection.
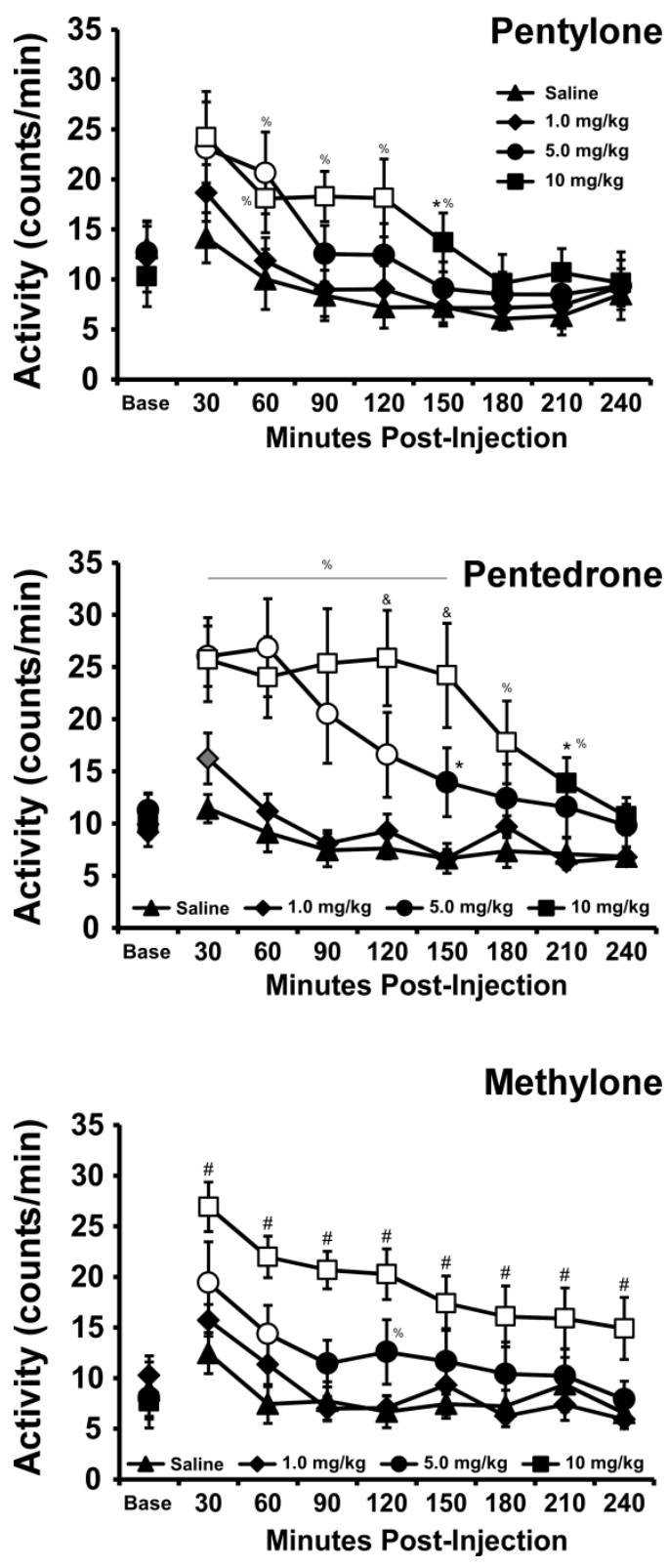

Figure 4: Mean ( $\pm S E M)$ activity rates of female rats $(N=8)$ following injection with pentylone, pentedrone or methylone. Significant differences from the baseline, within drug/dose, are indicated by symbols filled with gray and differences from both vehicle and baseline with open symbols. Significant differences from all other dose conditions are indicated with \#, from the $5 \mathrm{mg} / \mathrm{kg}$ dose with \& and from $1 \mathrm{mg} / \mathrm{kg}$ by $\%$ (line indicates both 5 and $10 \mathrm{mg} / \mathrm{kg}$ differ from $1 \mathrm{mg} / \mathrm{kg}$ ). Base = baseline. 
3.2.1.3 Methylone: There was a significant effect of time $[F(8,56)=27.5 ; P<0.0001]$, of dose $[F(3,21)$ $=28.23 ; \mathrm{P}<0.0001]$ and an interaction of time with dose $[\mathrm{F}(24,168)=3.23 ; \mathrm{P}<0.0001]$ on activity following methylone injection (Figure 4). The post-hoc test confirmed activity was significantly higher compared with vehicle after $5.0 \mathrm{mg} / \mathrm{kg}$ dose (30-60 minutes after injection) and higher than after all three other dosing conditions following the $10.0 \mathrm{mg} / \mathrm{kg}$ dose (30-240 minutes). Activity was also significantly higher 120 minutes after the $5 \mathrm{mg} / \mathrm{kg}$ dose compared with the $1 \mathrm{mg} / \mathrm{kg}$ dose.

\subsubsection{Temperature:}

Body temperature was not substantially changed in the female rats for any of these studies (data not shown). Mean body temperature did not vary more than $0.5^{\circ} \mathrm{C}$ from the baseline temperature in any of the dosing conditions.

\subsection{Intravenous Self-Administration of Substituted Cathinones in Female Rats}

\subsubsection{Acquisition}

The two groups of female rats self-administered similar numbers of infusions, i.e. of pentedrone $(0.2$ $\mathrm{mg} / \mathrm{kg}$ ) and $\alpha-P V P(0.05)$, during acquisition (Figure 5). The ANOVA confirmed a significant effect of

Sessions of acquisition $[F(12,180)=9.06$;

$P<0.0001]$, but not of Drug or of the interaction of factors.

\subsubsection{Dose-Substitution}

A total of $\mathrm{N}=10(\mathrm{~N}=6$ pentedrone-trained, $\mathrm{N}=4$ a-PVP-trained) rats retained patent catheters throughout all of the initial dose-substitution studies. Ascending and descending limbs of the dose-effect function were observed for pentedrone, pentylone and methylone, whereas a monotonic descending limb

was observed for $\alpha-P V P$ and $\alpha-P H P$ (Figure 6). Statistical analysis of the pentedrone, pentylone and
Figure 5: Mean ( $\pm S E M)$ infusions of of pentedrone $(0.2 \mathrm{mg} / \mathrm{kg})(\mathrm{N}=9)$ and $\alpha-P V P(0.05)(\mathrm{N}=8)$ obtained during the initial acquisition sessions. A significant difference from the first session indicated by *. 
methylone data confirmed significant effects of Drug $[F(2,18)=4.42 ; P<0.05]$ and of Dose $[F(4,36)=$ 12.35; $P<0.0001]$ on infusions obtained. The post-hoc test confirmed that significantly more infusions were obtained for at least one dose of each drug compared with vehicle and significantly more infusions of pentedrone and pentylone compared with methylone for at least one dose of each drug (see Figure 6). Statistical analysis of the $\alpha-P V P$ and $\alpha-P H P$ dose series confirmed significant effects of Drug $[F(1,9)$ $=25.59 ; \mathrm{P}<0.001]$, of Dose $[\mathrm{F}(4,36)=16.41 ; \mathrm{P}<0.0001]$ and of the interaction of Drug with Dose $[\mathrm{F}(4$, $36)=3.47 ; P<0.05]$ on infusions obtained. The post-hoc test confirmed that increased infusions of $\alpha-P H P$ were obtained, compared with $\alpha-P V P$, at the 0.025 and $0.05 \mathrm{mg} / \mathrm{kg} / \mathrm{inf}$ doses.
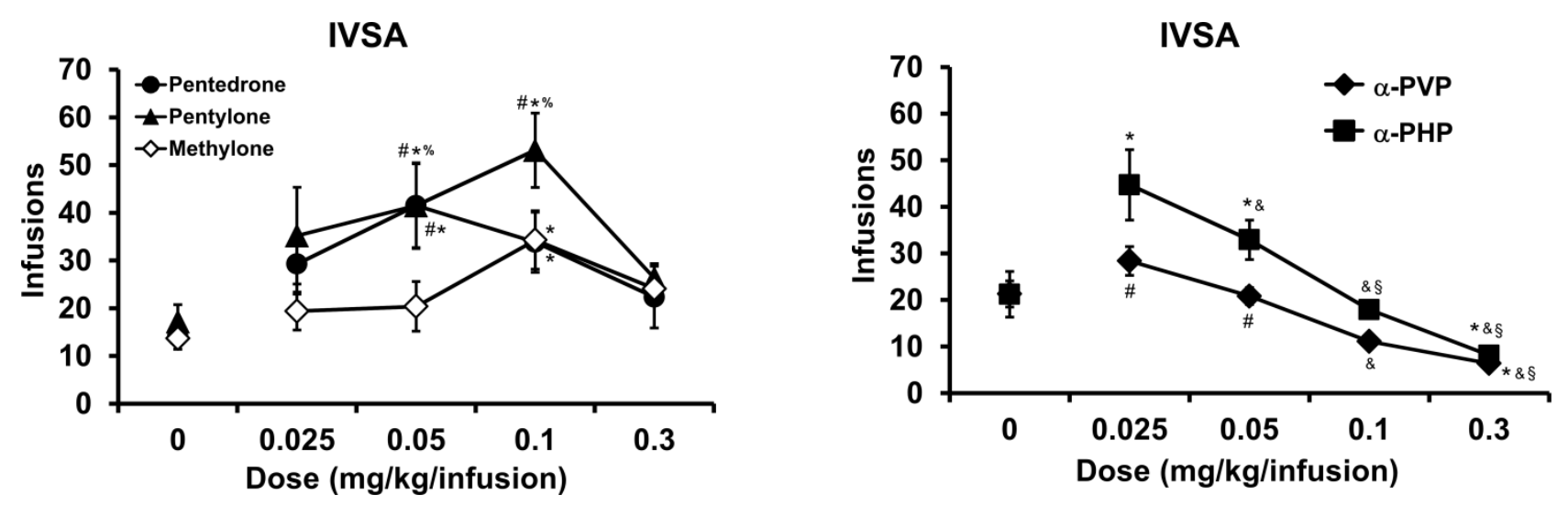

Figure 6: Mean ( $N=10 ; \pm S E M)$ infusions of Left) pentylone, pentedrone and methylone and Right) $\alpha$ - $P V P$ and $\alpha$ PHP obtained by female rats. A significant difference from vehicle is indicated with *, from the $0.025 \mathrm{mg} / \mathrm{kg}$ dose with \&, from the $0.05 \mathrm{mg} / \mathrm{kg}$ dose with $\S$, from the $0.3 \mathrm{mg} / \mathrm{kg}$ dose by $\%$ and a significant difference from methylone and $\alpha-P H P$, respectively, is indicated with \#.

A follow-up dose-substitution was conducted to evaluate lower dose (0.0125) of $\alpha$-PVP and $\alpha$ PHP (Figure 7); a total of $\mathrm{N}=5$ completed this final phase of the study with patent catheters. The primary analysis compared infusions obtained in seven conditions for this final dose series (i.e., saline and $0.0125,0.025,0.1 \mathrm{mg} / \mathrm{kg} / \mathrm{inf}$ for each of the two compounds). The ANOVA confirmed a main effect of dose $[F(3,12)=26.47 ; P<0.0001]$ but not of drug identity or any interaction; the Tukey post-hoc effects are summarized on Figure 7. Because only part of the original group completed the follow-up, the original curves for this subset of animals is graphed for comparison. Statistical analysis within-drug did not confirm any difference in infusions obtained for the overlapping doses (e.g., 0.0, 0.025, 0.1 mg/kg/inf) from the first to second dose-response evaluations. 
$\alpha-P V P$

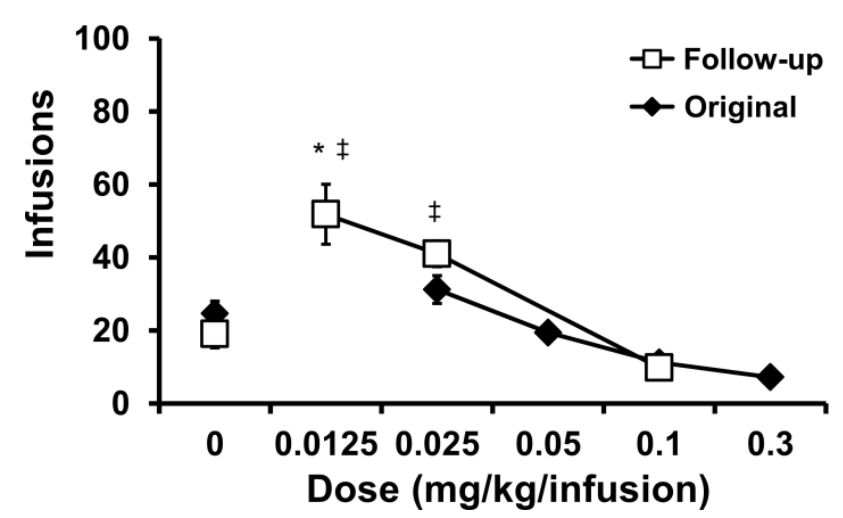

$\alpha-P H P$

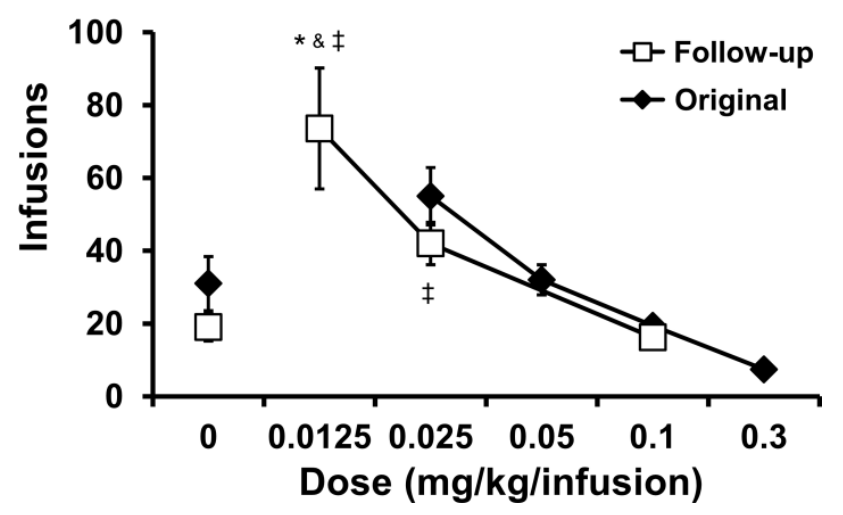

Figure 7: Mean $(N=5 ; \pm S E M)$ infusions of $\alpha-P V P$ and $\alpha-P H P$ obtained by female rats. $A$ significant difference from vehicle is indicated with ${ }^{*}$, from the $0.025 \mathrm{mg} / \mathrm{kg}$ dose with \& and from the $0.1 \mathrm{mg} / \mathrm{kg}$ dose with $\neq$.

\section{Discussion}

The study directly compared the psychostimulant effects of pentedrone, pentylone and methylone on measures of spontaneous locomotor activity and operant reward. Peak increases in activity rates were similar across all three compounds demonstrating similar efficacy; however, the locomotor effects of pentylone and methylone dissipated more quickly than those of pentedrone. Similar dose relationships were observed across male and female rat groups within and between the drugs, thus the outcome generalized across sex and across minor differences in age. The locomotor stimulant effects were of a similar magnitude to those observed for mephedrone, a-PVP and MDPV in prior investigations using similar methods, but appeared to last longer, i.e., more consistent with the duration of locomotor effects described for MDMA or methamphetamine (Aarde et al, 2013b; Miller et al, 2013a; Wright et al, 2012). Peak locomotor stimulant effects of $\alpha-P V P$ and MDPV were observed at $1.0 \mathrm{mg} / \mathrm{kg}$, i.p. with reductions in activity observed after $5.6-10 \mathrm{mg} / \mathrm{kg}$ MDPV in a prior study (Aarde et al, 2013b). In this study pentedrone, pentylone and methylone exhibited a threshold for increased activity above $1 \mathrm{mg} / \mathrm{kg}$ and essentially linear increases in locomotor activity up to $10 \mathrm{mg} / \mathrm{kg}$, i.p. suggesting less potency as locomotor stimulants compared with either a-PVP or MDPV. This was also the case for the induction of alternate behavior that interferes with locomotion which was not observed in this study at the highest doses of 
pentedrone, pentylone or methylone evaluated. In this, these three substituted cathinones appear to be more similar to mephedrone or MDMA and less similar to $\alpha-P V P$ or MDPV.

The intravenous self-administration (IVSA) study found a great deal of overlap in the dose-effect functions for pentylone and pentedrone, with a slight rightward shift of that for pentylone compared with pentedrone, indicating a potency difference. This contrasts with a prior MDPV/a-PVP comparison (Aarde et al, 2015a) where the 3,4-methylenedioxy motif appeared to convey no differences in potency or efficacy for the common structure. The function for methylone in this study reflected potency very similar to that of pentylone, however there was evidence for a reduction in peak responding (i.e., efficacy) of methylone compared with either pentylone or pentedrone. Evidence for the ascending and descending limbs of dose-effect functions was obtained for pentylone, pentedrone and methylone, thereby enhancing confidence that the full effective range was assessed. In contrast, only the descending limb for the $\alpha$ PVP and $\alpha-P H P$ compounds was described over the $0.0125-0.3 \mathrm{mg} / \mathrm{kg} / \mathrm{infusion}$ range which is consistent with higher potency as reinforcers compared with the other three compounds. The addition of the 0.0125 $\mathrm{mg} / \mathrm{kg}$ dose in the follow-up study further confirmed this potency shift, but more importantly it confirmed that efficacy of $\alpha-P V P$ and $\alpha-P H P$ is as high as, or higher than, the other cathinones since peak responding was observed when a $0.0125 \mathrm{mg} / \mathrm{kg} / \mathrm{infusion}$ dose was available. Although the primary focus here was not on $\alpha-P V P$ and $\alpha-P H P$, which were included mostly as positive controls for the behavioral procedure, it is notable that $\alpha$-PHP exhibited slightly more efficacy than did $\alpha$-PVP. These compounds produce nearly identical inhibition of the DAT (Eshleman et al, 2017; Kolanos et al, 2015) and thus it would be of interest to determine what other pharmacological properties confer this difference in reinforcing efficacy. The reduced efficacy of methylone compared with pentedrone or pentylone is as would be predicted from the efficacy of methylone as a releaser of serotonin (Eshleman et al, 2013; Eshleman et al, 2017; Simmler et al, 2013; Simmler et al, 2014). Self-administration of methylone escalates under long $(6 \mathrm{~h})$ daily access conditions much more than does IVSA of MDMA despite only slightly enhanced IVSA under shorter (2 h) access conditions (Nguyen et al, 2016b; Vandewater et al, 2015). The dose-substitution data under short access conditions presented here suggest that pentylone and pentedrone would exhibit escalated intakes at least as great as those for methylone, and 
significantly higher than the IVSA of MDMA, under long access conditions. Nevertheless, the contrast of IVSA of methylone with MDMA under short- and long-access conditions cautions that any given preclinical model is limited in terms of predicting real-world abuse liability. Further differences or similarities across the entactogen cathinones might emerge with future studies that incorporate, e.g., choice procedures, IVSA under a Progressive Ratio schedule of reinforcement, etc.

Thermoregulatory impact was negligible for any of the three substituted cathinones under the tested ambient conditions and doses administered. This is consistent with a lack of temperature disruption in a prior study after $30 \mathrm{mg} / \mathrm{kg}$, s.c., pentylone (Grecco et al, 2016); however, that report also found a pronounced hyperthermia after methylone $(30 \mathrm{mg} / \mathrm{kg}$, s.c. $)$. It is unknown at present if cathinones categorically convey less risk of hyperthermia compared with amphetamine derivatives, but the 4-methyl substituted methcathinone (mephedrone) appears to mostly lower body temperature in conditions where MDMA produces hyperthermia (Miller et al, 2013a; Wright et al, 2012). Full determination of the risks of pentylone, pentedrone or methyone for unregulated temperature disruption would likely require higher doses administered at higher ambient temperatures.

In conclusion, pentedrone and pentylone are effective locomotor stimulants and function as reinforcers in the self-administration model. Potency differences between the two are subtle, showing that in this context the 3,4-methylenedioxy motif does not convey the substantial difference in behavioral effect that it does when added to methamphetamine. These compounds share the extended $\alpha$-alkyl chain present on MDPV and a-PVP but appear to be less potent than either in comparison with prior findings. This suggests the pyrrolidine motif is critical to the high potency of those compounds compared with pentylone or pentedrone. 


\section{Funding and Disclosure:}

This work was funded by support from the United States Public Health Service National Institutes of Health (R01DA024705, R01DA042211) which had no direct input on the design, conduct, analysis or publication of the findings. The authors declare no competing financial interests. This is manuscript \#29517 from The Scripps Research Institute. 


\section{References}

Aarde SM, Angrish D, Barlow DJ, Wright MJ, Jr., Vandewater SA, Creehan KM, et al (2013a). Mephedrone (4-methylmethcathinone) supports intravenous self-administration in Sprague-Dawley and Wistar rats. Addiction biology 18(5): 786-799.

Aarde SM, Creehan KM, Vandewater SA, Dickerson TJ, Taffe MA (2015a). In vivo potency and efficacy of the novel cathinone alpha-pyrrolidinopentiophenone and 3,4-methylenedioxypyrovalerone: selfadministration and locomotor stimulation in male rats. Psychopharmacology 232(16): 3045-3055.

Aarde SM, Huang PK, Creehan KM, Dickerson TJ, Taffe MA (2013b). The novel recreational drug 3,4methylenedioxypyrovalerone (MDPV) is a potent psychomotor stimulant: self-administration and locomotor activity in rats. Neuropharmacology 71: 130-140.

Aarde SM, Miller ML, Creehan KM, Vandewater SA, Taffe MA (2015b). One day access to a running wheel reduces self-administration of D-methamphetamine, MDMA and methylone. Drug and alcohol dependence 151: 151-158.

Aarde SM, Taffe MA (2017). Predicting the Abuse Liability of Entactogen-Class, New and Emerging Psychoactive Substances via Preclinical Models of Drug Self-administration. Current topics in behavioral neurosciences 32: 145-164.

Adamowicz P, Gieron J, Gil D, Lechowicz W, Skulska A, Tokarczyk B (2016). The prevalence of new psychoactive substances in biological material - a three-year review of casework in Poland. Drug testing and analysis 8(1): 63-70.

Angoa-Perez M, Anneken JH, Kuhn DM (2017). Neurotoxicology of Synthetic Cathinone Analogs. Current topics in behavioral neurosciences 32: 209-230.

Bonano JS, Glennon RA, De Felice LJ, Banks ML, Negus SS (2014). Abuse-related and abuse-limiting effects of methcathinone and the synthetic "bath salts" cathinone analogs

methylenedioxypyrovalerone (MDPV), methylone and mephedrone on intracranial self-stimulation in rats. Psychopharmacology 231(1): 199-207.

Brunt TM, Atkinson AM, Nefau T, Martinez M, Lahaie E, Malzcewski A, et al (2017). Online test purchased new psychoactive substances in 5 different European countries: A snapshot study of chemical composition and price. The International journal on drug policy 44: 105-114.

Creehan KM, Vandewater SA, Taffe MA (2015). Intravenous self-administration of mephedrone, methylone and MDMA in female rats. Neuropharmacology 92: 90-97.

Dalley JW, Laane K, Theobald DE, Pena Y, Bruce CC, Huszar AC, et al (2007). Enduring deficits in sustained visual attention during withdrawal of intravenous methylenedioxymethamphetamine selfadministration in rats: results from a comparative study with d-amphetamine and methamphetamine. Neuropsychopharmacology : official publication of the American College of Neuropsychopharmacology 32(5): 1195-1206.

Drug Enforcement Administration DoJ (2014). Schedules of controlled substances: temporary placement of 10 synthetic cathinones into Schedule I. Final order. Federal register 79(45): 12938-12943. 
Drug Enforcement Administration DoJ (2017). Schedules of Controlled Substances: Placement of 10 Synthetic Cathinones Into Schedule I. Final rule. Federal register 82(39): 12171-12177.

Elliott S, Evans J (2014). A 3-year review of new psychoactive substances in casework. Forensic science international 243C: $55-60$.

Eshleman AJ, Wolfrum KM, Hatfield MG, Johnson RA, Murphy KV, Janowsky A (2013). Substituted methcathinones differ in transporter and receptor interactions. Biochemical pharmacology 85(12): 1803-1815.

Eshleman AJ, Wolfrum KM, Reed JF, Kim SO, Swanson T, Johnson RA, et al (2017). Structure-Activity Relationships of Substituted Cathinones, with Transporter Binding, Uptake, and Release. The Journal of pharmacology and experimental therapeutics 360(1): 33-47.

Gatch MB, Rutledge MA, Forster MJ (2015). Discriminative and locomotor effects of five synthetic cathinones in rats and mice. Psychopharmacology 232(7): 1197-1205.

Gatch MB, Taylor CM, Forster MJ (2013). Locomotor stimulant and discriminative stimulus effects of 'bath salt' cathinones. Behavioural pharmacology.

Grecco GG, Sprague JE (2016). Impact of Functional Group Modifications on Designer Phenethylamine Induced Hyperthermia. Chem Res Toxicol 29(5): 871-878.

Huang PK, Aarde SM, Angrish D, Houseknecht KL, Dickerson TJ, Taffe MA (2012). Contrasting effects of d-methamphetamine, 3,4-methylenedioxymethamphetamine, 3,4-methylenedioxypyrovalerone, and 4-methylmethcathinone on wheel activity in rats. Drug and alcohol dependence 126(1-2): 168175.

Hwang JY, Kim JS, Oh JH, Hong SI, Ma SX, Jung YH, et al (2017). The new stimulant designer compound pentedrone exhibits rewarding properties and affects dopaminergic activity. Addiction biology 22(1): 117-128.

Karlsson L, Andersson M, Kronstrand R, Kugelberg FC (2014). Mephedrone, Methylone and 3,4Methylenedioxypyrovalerone (MDPV) Induce Conditioned Place Preference in Mice. Basic \& clinical pharmacology \& toxicology.

Kiyatkin EA, Kim AH, Wakabayashi KT, Baumann MH, Shaham Y (2015). Effects of Social Interaction and Warm Ambient Temperature on Brain Hyperthermia Induced by the Designer Drugs Methylone and MDPV. Neuropsychopharmacology : official publication of the American College of Neuropsychopharmacology 40(2): 436-445.

Kolanos R, Sakloth F, Jain AD, Partilla JS, Baumann MH, Glennon RA (2015). Structural Modification of the Designer Stimulant alpha-Pyrrolidinovalerophenone (alpha-PVP) Influences Potency at Dopamine Transporters. ACS chemical neuroscience 6(10): 1726-1731.

Liakoni E, Dolder PC, Rentsch K, Liechti ME (2015). Acute health problems due to recreational drug use in patients presenting to an urban emergency department in Switzerland. Swiss medical weekly 145: w14166.

Liveri K, Constantinou MA, Afxentiou M, Kanari P (2016). A fatal intoxication related to MDPV and pentedrone combined with antipsychotic and antidepressant substances in Cyprus. Forensic science international 265: 160-165. 
Madras BK (2017). The Growing Problem of New Psychoactive Substances (NPS). Current topics in behavioral neurosciences 32: 1-18.

Marusich JA, Grant KR, Blough BE, Wiley JL (2012). Effects of synthetic cathinones contained in "bath salts" on motor behavior and a functional observational battery in mice. Neurotoxicology 33(5): 13051313.

Miller ML, Creehan KM, Angrish D, Barlow DJ, Houseknecht KL, Dickerson TJ, et al (2013a). Changes in ambient temperature differentially alter the thermoregulatory, cardiac and locomotor stimulant effects of 4-methylmethcathinone (mephedrone). Drug and alcohol dependence 127(1-3): 248-253.

Miller ML, Moreno AY, Aarde SM, Creehan KM, Vandewater SA, Vaillancourt BD, et al (2013b). A methamphetamine vaccine attenuates methamphetamine-induced disruptions in thermoregulation and activity in rats. Biological psychiatry 73(8): 721-728.

National Research Council (U.S.). Committee for the Update of the Guide for the Care and Use of Laboratory Animals., Institute for Laboratory Animal Research (U.S.), National Academies Press (U.S.) (2011). Guide for the care and use of laboratory animals: Eigth Edition. 8th edn. National Academies Press,: Washington, D.C., pp xxv, 220 p.

Negus SS, Banks ML (2017). Decoding the Structure of Abuse Potential for New Psychoactive Substances: Structure-Activity Relationships for Abuse-Related Effects of 4-Substituted Methcathinone Analogs. Current topics in behavioral neurosciences 32: 119-131.

Nguyen JD, Aarde SM, Cole M, Vandewater SA, Grant Y, Taffe MA (2016a). Locomotor Stimulant and Rewarding Effects of Inhaling Methamphetamine, MDPV, and Mephedrone via Electronic CigaretteType Technology. Neuropsychopharmacology : official publication of the American College of Neuropsychopharmacology 41(11): 2759-2771.

Nguyen JD, Grant Y, Creehan KM, Vandewater SA, Taffe MA (2016b). Escalation of intravenous selfadministration of methylone and mephedrone under extended access conditions. Addiction biology.

Odoardi S, Romolo FS, Strano-Rossi S (2016). A snapshot on NPS in Italy: Distribution of drugs in seized materials analysed in an Italian forensic laboratory in the period 2013-2015. Forensic science international 265: 116-120.

Papaseit E, Molto J, Muga R, Torrens M, de la Torre R, Farre M (2017). Clinical Pharmacology of the Synthetic Cathinone Mephedrone. Current topics in behavioral neurosciences 32: 313-331.

Schenk S (2009). MDMA self-administration in laboratory animals: a summary of the literature and proposal for future research. Neuropsychobiology 60(3-4): 130-136.

Schindler CW, Thorndike EB, Goldberg SR, Lehner KR, Cozzi NV, Brandt SD, et al (2015). Reinforcing and neurochemical effects of the "bath salts" constituents 3,4-methylenedioxypyrovalerone (MDPV) and 3,4-methylenedioxy-N-methylcathinone (methylone) in male rats. Psychopharmacology.

Simmler LD, Buser TA, Donzelli M, Schramm Y, Dieu LH, Huwyler J, et al (2013). Pharmacological characterization of designer cathinones in vitro. British journal of pharmacology 168(2): 458-470.

Simmler LD, Rickli A, Hoener MC, Liechti ME (2014). Monoamine transporter and receptor interaction profiles of a new series of designer cathinones. Neuropharmacology 79: 152-160. 
Sykutera M, Cychowska M, Bloch-Boguslawska E (2015). A Fatal Case of Pentedrone and alphaPyrrolidinovalerophenone Poisoning. Journal of analytical toxicology 39(4): 324-329.

Taffe MA, Creehan KM, Vandewater SA (2015). Cannabidiol fails to reverse hypothermia or locomotor suppression induced by Delta(9) -tetrahydrocannabinol in Sprague-Dawley rats. British journal of pharmacology 172(7): 1783-1791.

Vandewater SA, Creehan KM, Taffe MA (2015). Intravenous self-administration of entactogen-class stimulants in male rats. Neuropharmacology 99: 538-545.

Watterson LR, Hood L, Sewalia K, Tomek SE, Yahn S, Johnson CT, et al (2012). The Reinforcing and Rewarding Effects of Methylone, a Synthetic Cathinone Commonly Found in "Bath Salts". J Addict Res Ther S9:002(doi:10.4172/2155-6105.S9-002): 1-8.

Wright MJ, Jr., Angrish D, Aarde SM, Barlow DJ, Buczynski MW, Creehan KM, et al (2012). Effect of ambient temperature on the thermoregulatory and locomotor stimulant effects of 4methylmethcathinone in Wistar and Sprague-Dawley rats. PloS one 7(8): e44652. 